REVISTA DE DERECHO UNED, NÚM. 9, 2011

\title{
LA CONSTITUCIONALIZACIÓN DE DEBERES
}

\author{
Juan Manuel Goig Martínez \\ Profesor Titular de Derecho Constitucional \\ Universidad Nacional de Educación a Distancia
}

Resumen: El estudio de los deberes constitucionales no ha recibido suficiente atención de la doctrina, a pesar de su pronta aparición en el constitucionalismo y de la importancia alcanzada en nuestros días. Con la evolución del Estado liberal y su tránsito al Estado Social de Derecho, el valor jurídico de los deberes ha variado, pues su incorporación en los textos constitucionales modernos, paralelamente a la idea de la Constitución como norma jurídica, y la concepción social del Estado de Derecho, fundado en la solidaridad, la dignidad, el trabajo y la prevalencia del interés general, se traduce en la vigencia inmediata de los derechos fundamentales, pero también en la sanción constitucional al incumplimiento de los deberes constitucionales.

Palabras clave: deberes constitucionales; naturaleza; fundamento, Constitución Española.

Abstract: The study of constitutional duties has not received sufficient attention from the doctrine, despite its early appearance on constitutionalism and the importance achieved today. With the evolution of the liberal state and its transition to the Rule of Law, the legal value of homework has changed since its incorporation in the modern constitutions parallel to the idea of the Constitution as law, and social conception of the State of law, based on solidarity, dignity, work and the prevalence of general interest, results in the immediate enforcement of fundamental rights, but also in the constitutional sanction to the breach of their constitutional duties.

Key words: constitutional obligations, nature, foundation, the Spanish Constitution. 
Sumario: 1. Introducción. La incorporación de los deberes en las Constituciones.-2. La Teoría General de los deberes constitucionales. Concepto, Fundamento y Naturaleza: 2.1. Concepto.-2.2. Naturaleza.-2.3. Fundamento de los deberes constitucionales.-3. Deberes emergentes de Tratados Internacionales.-3.1. El voto como deber. Sobre la naturaleza del sufragio.-4. Los deberes fundamentales en la Constitución española de 1978.-4.1. Otros deberes constitucionales.-4.2. El deber general de acatamiento y defensa de la Constitución.-4.3. Sistematización de los deberes constitucionales en la Constitución española.-5. Estudio pormenorizado de algunos deberes constitucionales en España.-5.1. El deber de defender a España.-5.2. El deber de contribuir al sostenimiento de los gastos públicos.-5.3. El deber de trabajar.-5.4. La objeción de conciencia en los deberes públicos. Bibliografía.

\section{INTRODUCCIÓN. LA INCORPORACIÓN DE DEBERES EN LAS CONSTITUCIONES}

El tema de los deberes constitucionales es, sin duda, uno de aquellos que han guardado silencio en el olvido. Escribir sobre nuestros derechos es excesivamente frecuente, en contraste con la escasísima divulgación doctrinal y jurisprudencial que se da a los deberes que tenemos como miembros de la sociedad política, y que constan en la parte dogmática de la Constitución, como normas de conducta obligatoria y exigible. Sin embargo, en los últimos tiempos, el tema de los deberes constitucionales ha empezado a ser más estudiado: la pulsión hacia el universalismo de los derechos, que ha conllevado también el replanteamiento de algunos aspectos de la cultura jurídica y política; las exigencias del desarrollo sostenible, con vistas a las generaciones futuras; y la debilidad que está afectando al Estado Social, que ha vuelto a proponer el tema de los deberes de solidaridad de los individuos y de los grupos, y a plantear la función de las instituciones estatales, parecen ser las razones a que obedece este cambio de tendencia en el estudio de los deberes ${ }^{1}$.

Hasta antes de la Revolución Francesa de 1789, los deberes fueron considerados dentro de la órbita de la moral, y a partir de ella se fueron reconociendo jurídicamente-especialmente en las Constituciones Políticas- sobre la base de los principios de «no hacer a los demás lo

${ }^{1}$ Lanchester, F., «Los deberes constitucionales en el derecho comparado» en ReDCE, año 7, nº 13, 2010, págs 67 y 68. 
que no queremos que nos hagan a nosotros mismos" $\mathrm{y}$ "hacer aquello que quisiéramos que nos hagan a nosotros». La Declaración de los Derechos del Hombre de 1789 reenvía a la conexión entre derechos y deberes. En el texto de la Constitución Francesa de 1793 se incorporan como deberes los de «... servir a la sociedad, vivir sometido a las leyes y respetar a sus órganos, mantener y respetar las propiedades, y defender a la patria y a sus principios de libertad, de igualdad y de propiedad cada vez que se sea llamado a ello» ${ }^{2}$. Es la Constitución de 1795 la que evidencia, además de que la declaración de los derechos contenía obligaciones específicas para los poderes públicos -en concreto para el legislador-que «le maintien de la société demande que ceux que la composent connaissent et remplissent également leurs devoirs» ${ }^{3}$.

Tiempo después, se incorporarían en muchas Constituciones Políticas los denominados «deberes recíprocos» del ciudadano para con el Estado (el amor a la patria, el servicio y la defensa del orden republicano, la participación en los cargos públicos, y el deber de votar, el trabajo y la obediencia a las normas) y de éste respecto a aquéllos (de protección del ciudadano, «en su persona, su familia, su religión, su propiedad y su trabajo».

Finalmente, ya en el constitucionalismo más contemporáneo, incluso en los textos más moderados, se incluirán otros deberes para los ciudadanos a los que se denominarán como «fundamentales» o «substanciales», especialmente los que se refieren al sostenimiento de las cargas públicas y a la defensa de la nación.

La concepción de deberes como correlativos a los derechos, ha constituido una secuencia desde el origen del constitucionalismo a finales del siglo XVIII hasta nuestros días, tal como señala la Declaración Universal de Derechos Humanos en su artículo 29.1 «Toda persona tiene deberes respecto a la comunidad, pues sólo ella puede desarrollar libre y permanentemente su personalidad»; consagrando uno de los principios esenciales del orden constitucional, en virtud del cual, todo derecho comporta una obligación, y todo titular de un derecho tiene necesariamente relación con un sujeto obligado.

Como ha indicado Bobbio ${ }^{4}$, derecho y deber son como la cara y la cruz de una moneda cuyo derecho y revés depende de la posición de

\footnotetext{
2 Peces Barba, G., «Los deberes constitucionales», en DOXA. Cuadernos de Filosofía, Universidad de Alicante, n 4, 1987, pág. 331.

3 «La supervivencia de la sociedad exige que aquellos que la componen conozcan y cumplan igualmente sus deberes».

${ }^{4}$ Bobbio, N., Teoría General de la Política, Trotta, 2003, pág. 513.
} 
quien la mira. En la historia del pensamiento moral, político y jurídico, dicha moneda fue durante mucho tiempo examinada más por el lado de los deberes que por el de los derechos. Para que fuera posible pasar del enunciado del código de deberes al código de derechos fue necesaria una revolución, y que se comenzase a ver el problema no ya sólo desde el punto de vista del gobernante o de la sociedad sino también desde la óptica del individuo, y que se pasara de una perspectiva moral y ética a una perspectiva jurídica.

Abordar el tema de los deberes en el Estado Social de Derecho no significa volver a invertir el sentido de la moneda para revivir fantasmas del pasado o para reintroducir como guía del ordenamiento jurídico el postulado según el cual «Cada cual tiene deberes y para con todos, y nadie tiene derecho alguno propiamente dicho... En otros términos nadie posee más derecho que el de cumplir siempre con su deber» ${ }^{5}$.

En el Estado de Derecho, los deberes no se justifican por una lógica de sujeción a la voluntad divina, al soberano absoluto o al líder providencial. En el Estado de Derecho el ejercicio de los derechos suponen el cumplimiento de obligaciones a ellos inherentes y en ese sentido los deberes encuentran su explicación y límites en la existencia de derechos ${ }^{6}$.

La teoría del contrato en la tradición de Hobbes, Locke y Rousseau, renovada actualmente, con sus respectivos matices, esencialmente en la teorías de Rawls, Dworkin y Alexy, sigue siendo en realidad el marco por excelencia en el que puede encuadrarse actualmente una aproximación a los deberes en un Estado democrático. De manera que el fundamento de los deberes se sustenta en la propia idea de contrato social, entendida como un acuerdo entre los ciudadanos para constituir una entidad estatal que promueva nuestro bienestar social, de modo que establezca necesariamente limitaciones a nuestros derechos y libertades, y, a su vez, cargas derivadas de la vida en común, perfectamente acorde con la idea de Estado Social, que lleva implícita una significación finalística que es alcanzar la equidad social.

El elemento «social» del Estado Social de Derecho no modifica en nada esas premisas. El concepto de Estado Social de Derecho se encamina a realizar la justicia social y la dignidad humana mediante la

5 SÁnchez Viamonte, C., Manual de Derecho Político, Ed. Bibliográfica Argentina, Buenos Aires, 1959, pág. 3.

6 Rivero, J., Les libertés Publiques, Puf, Paris, 1974. pág. 64. 
sujeción de las autoridades públicas y de los particulares a los principios, derechos y deberes sociales de orden constitucional.

Ahora bien, existe, sin duda, una dimensión moral y ética de los deberes, en la línea de Cicerón, Pufendorf, Kant y Ross, entre otros, que no puede desconocerse, aunque en un estado laico y en una sociedad pluralista, esa dimensión y los matices que plantea, deberán situarse, esencialmente, en la conciencia de cada individuo según sus creencias y deberán enmarcarse en el respeto del pacto fundamental que configura la Constitución.

Optar por una aproximación individualista y esencialmente jurídica del tema del tema de los deberes no significa descartar o negar la necesidad de que los individuos asuman en la sociedad deberes, obligaciones y responsabilidades para asegurar su funcionamiento, o que se desconozca la importancia de las convicciones, valores y creencias que existen en ella, o mucho menos que ellos resulte contrario a los fundamentos del carácter social del Estado.

Solo individuos libres, capaces de autodeterminarse, son los que al tiempo que ejercen sus derechos asumirán cabalmente los deberes y obligaciones que la convivencia impone para hacer viable la sociedad democrática y, particularmente, la realización de los retos que plantea el Estado Social de Derecho.

Los deberes deben entenderse, no como una negación o restricción de las garantías que les asisten a las personas y a los ciudadanos, sino como una contribución para la obtención de los fines esenciales del Estado, a través de los cuales se les imponen ciertas conductas, comportamientos o prestaciones con fundamento en la Constitución y la ley.

Con la evolución del Estado liberal y su tránsito al Estado Social de Derecho, el valor jurídico de los deberes ha variado, pues su incorporación en los textos constitucionales modernos, paralelamente a la idea de la Constitución como norma jurídica, y la concepción social del Estado de Derecho, fundado en la solidaridad, la dignidad, el trabajo y la prevalencia del interés general, se traduce en la vigencia inmediata de los derechos fundamentales, pero también en la sanción constitucional al incumplimiento de los deberes constitucionales.

De esta forma, los deberes consagrados en la Constitución han dejado de ser un «desideratum» del buen «pater familias», para convertirse en imperativos que vinculan a los particulares y de cuyo cumplimiento depende la convivencia pacífica. 
La democracia precisa de individuos comprometidos con los principios que esa misma democracia está defendiendo. No son suficientes el Parlamento, ni la Constitución, ni las leyes, para que las democracias funcionen: tiene que haber, al mismo tiempo, ciudadanos dispuestos a hacer suya la cultura democrática. De no ser así, tendremos, por un lado, un ordenamiento jurídico y unas instituciones dirigidas a unos fines, mientras, por el otro, discurren formas de vida con objetivos y fines que nada tienen que ver con los anteriores ${ }^{7}$.

\section{LA TEORÍA GENERAL DE LOS DEBERES CONSTITUCIONALES. CONCEPTO, FUNDAMENTO Y NATURALEZA}

\subsection{Concepto}

Podríamos considerar los deberes constitucionales como comportamientos que se imponen a los particulares de hacer, dar, o no hacer, en consideración a intereses que no son particulares, sino en beneficio de otros sujetos, o en beneficio de intereses generales de la comunidad política. La presencia de los deberes responde a la consideración al que el ciudadano debe participar en la comunidad, debe hacer algo a favor de la comunidad, que los beneficios de la ciudadanía no son gratuitos y que por tanto las personas tienen el deber ético y político de colaborar en beneficio de esa comunidad.

Los deberes constitucionales son aquellas conductas o comportamientos de carácter público, exigibles por la ley a la persona o al ciudadano, que imponen prestaciones físicas o económicas y que afectan, en consecuencia, la esfera de su libertad personal. Las restricciones a la libertad general sólo pueden estar motivadas por fundadas razones que determine el legislador. En este sentido, los deberes consagrados en la Constitución comprenden una habilitación al legislador para desarrollar y concretar la sanción por el incumplimiento de los parámetros básicos de la conducta social fijados por el constituyente. A las prestaciones que alude esta definición, agregaríamos las morales, o mejor, las éticas, que implican obligaciones íntimamente relacionadas con el respeto a los derechos de los demás y la contribución al bien común.

Para Rodríguez Bereijo ${ }^{8}$, «los deberes públicos, por contraposición

7 Camps, V., Paradojas del individualismo, Crítica, Barcelona, 1999, págs. 10 y 11.

8 Rodríguez BereiJo, Á., «El Deber de Contribuir como deber constitucional. Su 
a los derechos, son aquellas situaciones pasivas o de sujeción que se imponen a un sujeto para tutelar intereses que no son particulares suyos sino en beneficio del interés general de la comunidad», aunque esta conceptualización es incompleta, puesto que los deberes no sólo tienen una dimensión negativa, sino que también pueden consistir en hacer, respetar o actuar -dimensión positiva-, y se podría clasificar a los «Deberes Constitucionales» en tres tipos:

1. Los deberes de la personalidad, que son aquellos que se derivan de la condición de ciudadano o miembro de la comunidad.

2. Los deberes de función, que son aquellos establecidos para quienes asumen determinados cargos.

3. Los deberes de prestación, entre los que se encuentran los generales (que son válidos para todos los ciudadanos, como el servicio militar o el pago de tributos) y los especiales (que existen respecto a algunos de ellos como el caso de los vinculados a los funcionarios públicos).

Para Santi Romano ${ }^{9}$, los deberes pueden clasificarse en base a diversos criterios:

A) Por su contenido: se clasifican en deberes positivos o negativos. Los deberes positivos (de dar o de hacer) son menos frecuentes que los deberes negativos (de no hacer), y se traducen en obligaciones (excepto cuando se encuentran vinculados a funciones). Los deberes negativos pueden ser funcionales o no funcionales.-El contenido de los deberes negativos consiste en no cumplir voluntariamente determinados comportamientos.

B) Respecto de los sujetos pasivos, los deberes suelen ser generales o de grupo; aunque excepcionalmente, pueden existir deberes particulares (como los deberes de un funcionario público).Además, y en base a este mismo parámetro, los sujetos pasivos de los deberes, pueden ser las autoridades públicas o los restantes sujetos jurídicos.

C) Por su intrasmisibilidad. En general, los deberes -al igual que los poderes- son «intuito personae», pues no son trasmisibles.

significado jurídico». En: Revista Española de Derecho Financiero, Civitas, Madrid, N 125, enero-marzo de 2005, pág. 21.

9 Santi Romano: Principii di Diritto costituzionale generale, p. 117 y ss. Fragmentos de un diccionario jurídico, p. 114 y ss. 
D) Por su cumplimiento. Salvo disposición expresa en contrario, los deberes deben cumplirse por sus titulares en forma personal, sin poder recurrir a representantes.

G) Por el alcance, los deberes pueden ser genéricos o específicos. La generalidad no se refiere al objeto de los deberes -que se encuentra establecido por la propia norma constitucional-, sino que se refiere al comportamiento establecido en razón del deber mismo.-No obstante, en ciertas oportunidades, también se establecen deberes específicos, aunque carentes de sanción, por lo que siempre se requiere una ley que establezca las formas y los modos de cumplimiento de ese tipo de deberes.

\subsection{Naturaleza}

El reconocimiento expreso de deberes en los textos constitucionales no implicó un inmediato reconocimiento de su aplicación normativa, pues justamente en los siglos XVIII y XIX, toda disposición de carácter constitucional era considerada como meramente enunciativa, programática y no vinculante. Así, los deberes constitucionales fueron entendidos como manifestación última de las corrientes iusnaturalistas previas al Derecho moderno.

Esa carga iusnaturalista en el desarrollo conceptual originario de la idea de deber constitucional originó que, en un primer momento, se tenga la idea de que, en realidad, se trataba de una categoría inútil y prescindible. Los deberes constitucionales resultaban ser «elementos jurídicamente irrelevantes», debido a que no venían respaldados por elementos mandatorios o sancionadores que eran los que caracterizaban a una norma jurídica propiamente dicha.

Se pensó que los deberes constitucionales, en realidad, crean mandatos dirigidos al legislador más que una vinculación a la conducta en las personas, es decir, no crean una expectativa de comportamientos privados, sino una expectativa de actuación de los poderes públicos, por lo que siempre será necesario que el legislador intervenga, vía una norma de rango legal, diseñando una conducta que obligue a los ciudadanos y, a su vez, la correspondiente sanción en caso de incumplimiento.

En base a estas consideraciones previas, la interrogante giraba en torno a la siguiente cuestión: ¿qué mandato jurídico tienen los deberes constitucionales?, y la respuesta consideraba que la estructura 
normativa del deber es incompleta, en primer lugar porque en todos ellos nos aparece la remisión a la ley, el deber constitucional se caracteriza por ser un deber de configuración legal con lo cual estamos ante una estructura normativa incompleta, imperfecta por tanto su eficacia no puede ser directa. Otro gran elemento que hipoteca su eficacia directa es que no está prevista una sanción, el incumplimiento no está presente. Por tanto, será necesario adelantar que tendremos que distinguir entre deber constitucional y obligación de cumplimiento de los deberes constitucionales.

Lo que hace la Constitución es establecer deberes y el deber constitucional para convertirse en obligación requiere la intervención de la ley. Ahora bien, esto quiere decir, ¿que la Constitución únicamente establece deberes éticos o deberes políticos?. No, el deber tiene la fuerza normativa del resto de la Constitución. Tiene una fuerza normativa limitada porque su perfección depende de que intervenga la ley. Por tanto, el deber para convertirse en obligación jurídica requiere la intervención de la ley, reserva de ley que afecta, tanto a las obligaciones de hacer, como a las de dar. La ley es imprescindible, sin ley, solo desde la Constitución no pueden exigirse deberes jurídicos a los ciudadanos.

Sin embargo, a pesar del valor normativo de los deberes constitucionales, y de su importancia práctica para la realización de los valores del Estado social, la forma general como fueron consagrados en el texto de las Constituciones, hace que sea necesario concretar su contenido y alcance para poderlos aplicar.

Así que para que un deber constitucional sea exigible de un individuo en un caso concreto se requiere, a diferencia de lo que sucede con los derechos fundamentales que son directamente tutelables, de una decisión previa del legislador consistente en precisar el alcance del deber constitucional, en establecer si de éste se derivan obligaciones específicas y en definirlas, así como en señalar las sanciones correspondientes, respetando los principios de razonabilidad y proporcionalidad.

Los deberes que surgen de la Constitución sólo pueden ser exigidos a los particulares si media una norma legal que defina su alcance y significado de manera precisa. De esta forma, se entiende que los deberes enunciados en la Constitución cumplen la función de ser, principalmente patrones de referencia para la formación de la voluntad legislativa y de ser fundamento para la creación legal de obligaciones específicas que constituyan un desarrollo de la Constitución. 
En el trasfondo de esta inicial consideración de los deberes se observa la interpretación de que los deberes no imponen propiamente obligaciones jurídicas, puesto que no las cubren con las correspondientes sanciones, de manera que por sí solas, no bastan para reprimir una conducta contraria, o su incumplimiento.

Ahora bien, con el tránsito de la idea de Estado Social y Democrático de Derecho a la formación del denominado Estado Constitucional, hoy día se puede afirmar, sin ambages, que la Constitución tiene contenido normativo, por lo que todos los preceptos constitucionales tienen la condición de norma jurídica. Si la Constitución incluye en sus preceptos ciertos deberes, habrá que deducir que los mismos tienen carácter de normas jurídicas, de modo que han de ser verdaderas prestaciones exigibles. No todos los artículos de la Constitución tienen el mismo alcance y significación normativa, pero todos, rotundamente, enuncian efectivas normas jurídicas.

Por ello, resulta claro que los deberes constitucionales son comportamientos cuya exigencia proviene directamente de una norma constitucional y están destinados a facilitar su cumplimiento, pudiendo ser aplicables incluso al ciudadano concreto.

En buena medida, este enfoque reconoce que los deberes y obligaciones vendrían a ser dos especies de un género común, que es la norma jurídica. Ambos, se conceptualizarían como comportamientos positivos o negativos impuestos a un ciudadano en consideración a intereses en muchos casos no particularizables en él, que podrían beneficiar a otros sujetos o responder a los intereses del conjunto social. Cabe señalar que, desde un esquema kelseniano, se mantendría la «obligatoriedad» de los deberes constitucionales incorporándolos como «obligaciones jurídicas» y diferenciándolos de una noción vaga de «deber» como elemento prejurídico que se diferencia de la obligación en que aquél no es un concepto relacional, es incondicional, y es un fin en sí mismo.

Los deberes constitucionales no sólo lo serán de los ciudadanos sino también de los poderes públicos, de los órganos y de los funcionarios, puesto que, por un lado, el sometimiento de los gobernantes a la Ley, supone que las normas jurídicas regulan también el origen, la organización y el funcionamiento del poder, y de que el paso del Estado Liberal al Estado Social de Derecho atribuirá unas funciones positivas al poder público para la satisfacción igual de las necesidades humanas básicas, por otro. 
En términos históricos podríamos percibir una dimensión objetiva de los deberes, que está dada por el hecho de que han servido para la existencia y funcionamiento de la sociedad organizada en un tipo de Estado, podemos afirmar que en el diseño del Estado Constitucional actual, los deberes constitucionales se presentan para promover el cumplimiento de los fines constitucionales (entre otros, la libertad, la solidaridad y la justicia social) permitiendo el establecimiento -fundamentalmente normativo- de las herramientas requeridas para alcanzar esos fines.

Complementariamente, también cabe apreciar una dimensión subjetiva en vista a que con esos deberes, unidos a los derechos constitucionales, queda delimitado constitucionalmente el status del individuo en abstracto y globalmente.

Los deberes constitucionales no autorizan al operador jurídico para hacer interpretaciones extensivas que intenten ampliar, en perjuicio del ámbito de los derechos fundamentales, el campo de cobertura de tales deberes a situaciones que, por sus características y sentido, no guardan relación directa con el deber de que se trate.

Un deber constitucional no puede entenderse como la negación de un derecho, pues sería tanto como suponer en el constituyente, trampas a la libertad. Los deberes exigibles a las personas no pueden hacerse tan rigurosos que comprometan el núcleo esencial de sus derechos fundamentales.

En la medida en que cabe afirmar que los derechos constitucionales no son absolutos, que son susceptibles de modulación en función de los derechos de los demás y del ordenamiento jurídico, se ha de señalar también que los deberes constitucionales tampoco son absolutos y que en su aplicación concreta deben atender a los principios que al efecto se señalen en la propia Constitución.

\subsection{Fundamento de los deberes constitucionales}

Superado el inicial enfoque moral que se otorgaba por los teóricos a los deberes, en la actualidad, el fundamento de los deberes constitucionales lo encontramos en la justicia legal y en los principios de la ética social. A la inversa de lo que sucede con la justicia distributiva, que va de la sociedad a los miembros, la justicia legal (o social) va de los miembros a la sociedad, y en este caso, a la sociedad política. El sujeto de derecho no es aquí, indistintamente la comunidad o el público, sino el Estado, es decir, todo el conjunto de la organización que en- 
cuadra la comunidad nacional (punto de vista cívico o político, que responde al aspecto del bien público político), y esa misma comunidad incorporada (punto de vista social, que responde al aspecto del bien público social). Los deudores de la justicia legal son los individuos y los grupos privados, obligados en su calidad de miembros, y cualquiera que sea su rango en el Estado, de gobernantes o gobernados, a dar al todo social lo que le corresponde por parte de sus miembros. La «ordenación al bien común» que es objeto de la justicia legal, se refiere, por tanto, al respeto por los miembros del derecho estricto de la comunidad respecto a ellos: esta ordenación de las partes al todo se debe a la comunidad como un derecho provisto de exigibilidad.

La realización y contribución al bien común, fin del Estado, es el primer deber del miembro de la sociedad política, y su importancia es tan grande que incluso el miembro debe anteponer el interés general al interés particular. El bien común temporal y el bien particular (entendido como bien de la persona) están estrechamente relacionados. El hecho de que todos los hombres persigan esencialmente el mismo bien, lo convierte en tarea común. Todos deben, por tanto, contribuir a la creación de los presupuestos sociales que hacen asequible el perfeccionamiento personal. En otras palabras: todos están obligados a colaborar en la obtención del bien común, que goza así de un cierto carácter supraindividual, porque redundará en beneficio de todos y cada uno de los miembros del grupo social.

El problema de los deberes remite a la esencia del concepto de justicia, entendida como distribución y equilibrio de derechos y cargas, que la eficacia de los derechos implica la obligación para alguien de realizarlos, y que desde esa perspectiva es, en la Constitución, donde, en un Estado democrático, han de encontrarse los referentes que orientan el ejercicio de los derechos y la delimitación de las obligaciones que de dicho ejercicio se derivan, puesto que deben de ser fines esenciales del Estado, los de servir a la comunidad, promover la prosperidad general y garantizar la efectividad de los principios, derechos y deberes constitucionales, y los poderes públicos están instituidos para proteger a todas las personas.

Podíamos concluir este apartado afirmando que se ha superado el momento en el que en los ordenamientos contemporáneos de origen liberal y democrático, los deberes de todos los ciudadanos y los grupos estaban sujetos a la inviolabilidad de los derechos fundamentales, mientras que los deberes de los sujetos públicos se relacionaban con sus competencias. Hoy en día nos encontramos ante deberes inderogables de solidaridad política, económica y social, que representan 
una evolución del Estado liberal al Estado social, y que obligan por igual a los individuos y a los poderes públicos encargados de hacer un mundo mejor.

Los deberes constitucionales son incorporados a las Constituciones por una exigencia de solidaridad para la satisfacción de los intereses generales y comunes, muchas veces hecha efectiva mediante prestaciones, con los que el Estado pretende el concernimiento de todos, en régimen de igualdad, en la consecución de los objetivos estatales. Desde esta perspectiva, los deberes tienen una dimensión obligacional que viene exigida por el propio concepto de Estado social y democrático de Derecho ${ }^{10}$.

\section{DEBERES EMERGENTES DE NORMAS INTERNACIONALES}

Los deberes no sólo se encuentran regulados en las diversas Constituciones estatales, sino que, en mayor o menor medida, también se encuentran establecidos en todos los instrumentos relacionados directa o indirectamente con el denominado Derecho Internacional de los Derechos Humanos, como: la DADH, la DUDH, el PIDESC, el PIDCP, la CADH, y muchos otros. En este ámbito, la enumeración de deberes, no se agota en esos importantes instrumentos, sino que se encuentran esparcidos en casi todas las normas internacionales; razón por la cual, su estudio exhaustivo, escapa al alcance del presente trabajo.

En el ámbito internacional, la Declaración Americana de Derechos y Deberes (DADH) es la primera norma que incluye deberes, mediante una amplia enumeración de deberes, en especial en su capítulo segundo.

La DADH establece que todas las personas tienen los derechos y deberes consagrados en la misma, sin distinción de raza, sexo, idioma, credo, ni otra alguna (art. 2), y reconoce, junto a esta proclamación general del deber de igualdad, los siguientes deberes:

- Deber de convivencia social. Toda persona tiene el deber de convivir con las demás, de manera que todas y cada una puedan formar y desenvolver integralmente su personalidad (art. 29).

10 Cámara Villar, G., «Capítulo XXV. Los deberes constitucionales», en Balaguer Callejón, F. (Coord), Manual de Derecho Constitucional, Vol. II, Técnos, Madrid, 2005, pág. 345. 
- Deberes recíprocos entre padres e hijos. Toda persona tiene el deber de asistir, alimentar, educar y amparar a sus hijos menores de edad; y los hijos tienen el deber de honrar siempre a sus padres y el de asistirlos, alimentarlos y ampararlos cuando éstos los necesiten (art. 30).

- Deber de instrucción mínima. Toda persona tiene el deber de adquirir, al menos, la instrucción primaria (art. 31).

- Deber de sufragio. Toda persona tiene el deber de votar en las elecciones populares del país de que sea nacional, cuando esté legalmente capacitado para ello (art. 32).

- Deber de obediencia a la ley. Toda persona tiene el deber de obedecer a la ley y demás mandamientos legítimos de las autoridades de su país y de aquél en que se encuentre (art. 33).

- Deber de servir a la comunidad y a la Patria. Toda persona hábil tiene el deber de prestar los servicios civiles y militares que la Patria requiera para su defensa y conservación, y en caso de calamidad pública, los servicios de que sea capaz (art. 34). Asimismo las personas tienen el deber de desempeñar los cargos de elección popular que le correspondan en el Estado de que sea nacional.

- Deber de cooperar con la asistencia y la seguridad social. Toda persona tiene el deber de cooperar con el Estado y con la comunidad en la asistencia y seguridad sociales, de acuerdo con sus posibilidades y con las circunstancias (art. 35).

- Deber de pagar los impuestos establecidos por ley. Toda persona tiene el deber de pagar los impuestos establecidos por la ley para el sostenimiento de los servicios públicos (art. 36).

- Deber de trabajar. Toda persona tiene el deber de trabajar, dentro de su capacidad y posibilidades, a fin de obtener los recursos para su subsistencia o beneficio de la comunidad (art. 37).

- Deber de abstenerse de actividades políticas en país extranjero. Toda persona tiene el deber de no intervenir en las actividades políticas que, de conformidad con la ley, sean privativas de los ciudadanos del Estado en que sea extranjero (art. 38).

De acuerdo con la Declaración Universal de los Derechos Humanos (DUDH), toda persona tiene deberes respecto a la comunidad, puesto que sólo en ella puede desarrollar libre y plenamente su personalidad (art. 29). En el ámbito de Naciones Unidas, se ha sostenido que del art. 29 de la DUDH se derivan dos grupos de de- 
beres: los deberes internacionales para con la comunidad; y los deberes de la persona para con los demás.

A) Son deberes internacionales para con la comunidad:

1. El deber de utilizar su fuerza para mantener la paz y la seguridad internacionales.

2. El deber de abstenerse de realizar propaganda en favor de la guerra (PIDCP, art. 20.1).

3. El deber de abstenerse de realizar la apología del odio nacional, racial o religioso que constituya incitación a la discriminación, la hostilidad o la violencia (PIDCP, art. 20.2).

4. Los deberes para con la humanidad (arts. I y IV de la convención para la prevención y la sanción del Delito de Genocidio, y arts. I y III de la Convención Internacional sobre la Represión y el Castigo del Crimen de Apartheid.

5. El deber de respetar el Derecho internacional (Preámbulo de la Carta, y párrafo 51 del preámbulo de los Pactos internacionales).

6. El deber de respetar el Derecho humanitario.

B) Deberes de la persona para con los demás

También el PIDESC y el PIDCP, reconocen como deberes:

1. Deber de respeto a los otros individuos y a la comunidad. $\mathrm{El}$ individuo, por tener deberes respecto de otros individuos y de la comunidad a que pertenece-principio de solidaridad-, está obligado a procurar la vigencia y observancia de los derechos reconocidos en ambos Pactos (preámbulos).

2. Deber de asegurar el respeto a los demás y a la comunidad en el ejercicio de la libertad de expresión. El ejercicio del derecho a la libertad de expresión entraña deberes y responsabilidades especiales; por lo que puede estar sujeto a ciertas restricciones, expresamente fijadas por la ley y necesarias para: asegurar el respeto a los derechos o a la reputación de los demás; y la protección de la seguridad nacional, el orden público o la salud o la moral públicas (PIDCP, art. 19.3).

La Carta Africana de Derechos Humanos (CADH), contempla los siguientes deberes:

1. Deberes para con la familia, la comunidad y la humanidad. Toda persona tiene deberes para con la familia, la comunidad y la humanidad (Cap. V, art. 32.1). 


\section{Correlación e interacción entre deberes, derechos, segu-} ridad y bien común. Se establece que los derechos de cada persona están limitados por los derechos de los demás, por la seguridad de todos y por las justas exigencias del bien común, en una sociedad democrática (Cap. V, art. 32.2).

En el estudio de la enumeración que la Comunidad Internacional hace de los deberes, podemos determinar que no todos los deberes enunciados tienen la misma naturaleza, de manera que un análisis más pormenorizado determina que existen diferencias notables entre los deberes enunciados. Así, podemos encontrar:

1. Deberes de eficacia inmediata:

- La vinculación de todos los poderes públicos y todos los ciudadanos a la Constitución.

- La vinculación especial a los derechos y libertades constitucionales.

2. Deberes directamente vinculados a derechos fundamentales:

- Votar, siempre que se esté en capacidad legal para hacerlo. Con ello, se considera que el sufragio no es un derecho disponible por el individuo, sino una obligación jurídica impuesta al individuo en aras del funcionamiento armónico de la vida política del Estado.

- Dedicarse a un trabajo digno, de su elección, a fin de proveer el sustento propio y el de su familia para alcanzar el perfeccionamiento de su personalidad y contribuir al bienestar y progreso de la sociedad, en consonancia con la consideración de que el trabajo es un derecho, un deber y una función social que se ejerce con la protección y asistencia del Estado.

- Asistir a los establecimientos educativos para recibir educación obligatoria, en la consideración de que toda persona tiene derecho a una educación integral, de calidad, permanente, en igualdad de condiciones y oportunidades, sin más limitaciones que las derivadas de sus aptitudes, vocación y aspiraciones.

3. Deberes de configuración legal.

- Prestar los servicios civiles y militares que la Patria requiera para su defensa y conservación, de conformidad con lo establecido por la ley;

- Prestar servicios para el desarrollo estatal y social;

- Tributar, de acuerdo con la ley y en proporción a su capacidad contributiva, para financiar los gastos e inversiones públicas. Es de- 
ber fundamental del Estado garantizar la racionalidad del gasto público y la promoción de una administración pública eficiente.

4. Deberes de solidaridad y justicia social:

- Cooperar con el Estado en cuanto a la asistencia y seguridad social, de acuerdo con sus posibilidades;

- Actuar conforme al principio de solidaridad social, respondiendo con acciones humanitarias ante situaciones de calamidad pública o que pongan en peligro la vida o la salud de las personas;

- Proteger los recursos naturales del país, garantizando la conservación de un ambiente limpio y sano.

5. Deberes de democracia:

- Velar por el fortalecimiento y la calidad de la democracia, el respeto del patrimonio público y el ejercicio transparente de la función pública.

6. Deberes de abstención:

- Abstenerse de realizar todo acto perjudicial a la estabilidad, independencia o soberanía de los Estados.

\subsection{El voto como deber. Sobre la naturaleza del sufragio}

El sufragio es la expresión política de la voluntad individual. Su existencia tiene por objeto la participación del ciudadano en la designación de los representantes del pueblo, de determinados funcionarios públicos, o la aprobación o rechazo de ciertos actos de gobierno.

En una democracia representativa, la existencia y vigencia del sistema electoral es una pieza fundamental, ya que es en la elección de esos representantes por medio del voto de la ciudadanía, donde se encuentra uno de los elementos principales del sistema democrático.

Uno de los caracteres básicos del Estado democrático es el de la libre competencia por el poder, el de la elección disputada, libre, pacífica, periódica y abierta -sin exclusiones- por los electores, tanto de las personas como de los programas o partidos a los que los candidatos pertenecen. El signo inequívoco de la democracia pluralista -ante el ideal irrealizable de la democracia directa- es la articulación de un procedimiento mediante el cual los ciudadanos concurren periódicamente a la elección de una línea política determinada. A través 
del sufragio, los ciudadanos coadyuvan, como miembros del Estadocomunidad, a la conformación del Estado-aparato y, en consecuencia, a la integración funcional de toda la sociedad política.

Por medio del sufragio, los ciudadanos ejercen el derecho a participar en la determinación de la orientación política general mediante la designación de sus representantes o mediante la votación de aquellas propuestas que les sean sometidas. Cumple así dos funciones fundamentales que han hecho que el sufragio se arrogue el lugar preeminente en la vida política del Estado democrático liberal: la función electoral, que sirve para designar a los representantes, y la función normativa, que se emplea para iniciar una ley, aceptar o rechazar un texto legislativo e incluso para intervenir en la revisión constitucional. Estas funciones se resumen en una: la expresión de la opinión pública, en cuyos juicios suelen ir mezclados nombres de personas, doctrinas que encarnan y resoluciones que se prefieren ${ }^{11}$. Esta función del sufragio encarna tres efectos principales: producir representación, producir gobierno y ofrecer legitimación ${ }^{12}$.

Tradicionalmente, el sufragio ha sido considerado como un derecho, pero en algunos Estados tiene carácter obligatorio configurándose como un deber jurídicamente exigible: quien no concurre a votar sin causa justificada, es multado y no puede ejercer temporalmente empleos públicos, o sufre alguna otra penalización.

En el constitucionalismo comparado se encuentran ejemplos de la consideración del derecho al sufragio activo, no sólo como un derecho sino también como un deber. Se sitúa así, la obligatoriedad del voto en el ámbito de los deberes exigidos por la Constitución, al entender que la participación no constituye una opción, sino una exigencia de la sociedad a la que se pertenece. Los derechos y libertades que propugnaba el liberalismo exacerbado han dejado paso a una nueva concepción de la política, que integra al ciudadano en el pueblo, en el que descansa la soberanía. El cuerpo electoral, que algunos autores han considerado órgano constitucional del Estado, integrado por ciudadanos mayores de edad, adquiere un compromiso individual y social que no puede ser desconocido. Y, si bien, la aportación a la vida política no se reduce a la emisión del voto, ésta es la forma más elemental y, por ello, la más importante de participación. Podríamos decir que se trata del mínimo constitucional que no se puede ignorar, ni aun invocando la libertad de pensamiento o de

11 Vid. Pérez Serrano, N., Tratado de derecho político. Madrid, 1976.

12 Vid. Carreras, F. DE y Valles, J. M.: Las Elecciones, Barcelona, Bosch 1977. 
conciencia, porque los electores siempre disponen de la opción de votar en blanco.

No obstante, no falta quien considera al sufragio como una función pública, lo que implica una confluencia de derecho y deber. La definición del sufragio como toda manifestación de voluntad individual que tiene por objeto concurrir a la formación de la voluntad colectiva, con el fin de constituir el gobierno o decidir algún problema trascendental para los intereses de la Nación, determina la importancia del acto electoral, y hace que los votantes actúen como "funcionarios públicos», pues con la acción de votar contribuyen a lograr los objetivos del Estado.

En torno a esta caracterización jurídica del sufragio, se ha producido un intenso debate a partir de la Revolución francesa, cuyas posiciones principales son las siguientes:

La teoría del sufragio como derecho aparece conectada a la concepción rousseauniana de la soberanía popular, entendida como la suma de las fracciones de soberanía que corresponden a cada ciudadano. A partir de aquí se deduce que el sufragio es un derecho preestatal, innato a la personalidad. Para Rousseau, de la cualidad de ciudadano se deduce su derecho de voto.

La teoría del sufragio como función se conecta con la concepción sieyesiana de la soberanía nacional -la nación, ente distinto de cada uno de los ciudadanos que la componen, es la única soberana- de la que se deriva la separación entre el derecho de ser ciudadano (ius civitatís) y el derecho a ser elector (jus suifragii). De acuerdo con esta doctrina son titulares del "jus suffragii» aquellos ciudadanos que reúnan las condiciones determinadas por el legislador, que les coloca en una situación objetiva particular: se les pide que participen en la elección de los gobernantes; con ello no ejercen ningún derecho personal, sino que actúan en nombre y por cuenta del Estado, ejercen una función política ${ }^{13}$.

La lógica inherente a la concepción anterior conduce inevitablemente a admitir que el sufragio es un deber jurídico estricto; no es el sufragio -mantienen los que apoyan esta tesis- un derecho disponible por el individuo, sino una obligación jurídica impuesta al individuo en aras del funcionamiento armónico de la vida política del Estado. Aunque los teóricos del voto obligatorio sostienen que éste no coarta la libertad individual porque sólo obliga al ciudadano a participar

13 Vid. Cotteret, J. M. y Emeri, C., Les systémes électoraux. Paris, Puf, 1973. 
bajo la amenaza de una sanción, pero no impone deber alguno respecto del contenido del voto, consideramos que el sufragio que deja de ser libre en cuanto a la decisión primaria sobre su emisión, deja de ser auténtico sufragio.

A partir de estas teorías clásicas han surgido modernamente otras concepciones que tratan de enmarcar el sufragio bien como función estatal, bien como función pública no estatal, bien, finalmente, como derecho público subjetivo y función pública no estatal. Esta concepción última, flexible e híbrida, es la que ha sido acogida mayoritariamente -tanto doctrinalmente como en el Derecho Positivo- y permite clasificar al sufragio entre los derechos-función. El sufragio es, además de un derecho personal -aunque ejercido corporativamentede carácter funcional, una función, pues a través del mismo se procede a determinar la orientación de la política general, ya sea mediante la designación de los órganos representativos, ya sea mediante la votación de las propuestas que sean sometidas a la consideración del cuerpo electoral.

\section{LOS DEBERES FUNDAMENTALES EN LA CONSTITUCIÓN ESPAÑOLA DE 1978}

La Constitución española, como el resto de Constituciones de su entorno, además de reconocer derechos y libertades, impone ciertos deberes. Como es tradicional en el tratamiento constitucional de los deberes, éstos obedecen a los intereses generales de la colectividad, sin que exista alguien, en concreto, que nos pueda reclamar un comportamiento conforme a lo ordenado por la Constitución. Nadie personalmente puede sancionarnos por ello, sólo el Estado puede reclamarnos una determinada conducta, y ha de hacerlo conforme a las leyes. En ello, principalmente radica la diferencia entre el deber y la obligación. El deber se establece genéricamente y de modo abstracto en las leyes, mientras que la obligación nace de una relación individualizada y concreta con otro sujeto que puede exigir el efectivo cumplimiento de la conducta esperada, y si no se cumple puede dar lugar a una responsabilidad y a un perjuicio para el obligado.

La Constitución española formula deberes específicos con un contenido obligacional concretado legalmente, como garantía para los ciudadanos, exigibles por los poderes públicos y cuyo incumplimiento puede dar lugar a sanciones. 
Si bien no es posible establecer un sistema de deberes constitucionales, puesto que éstos están diseminados a lo largo de todo el Texto Constitucional, sí podemos afirmar que la Sección Segunda del Capítulo II del Título I, concretamente bajo la rúbrica «De los derechos y deberes de los ciudadanos», establece los que podrían ser considerados como «deberes constitucionales fundamentales», que son:

1. El derecho y el deber de los españoles de defender a España. La ley fijará las obligaciones militares de los españoles y regulará, con las debidas garantías, la objeción de conciencia, así como las demás causas de exención del servicio militar obligatorio, pudiendo imponer, en su caso, una prestación social sustitutoria. (art. 30. CE).

2. El deber de prestar un servicio civil para el cumplimiento de fines de interés general (art. 30.3).

3. Los deberes en caso de grave riesgo, catástrofe o calamidad pública (art. 30.4).

4. El deber de todos de contribuir al sostenimiento de las cargas públicas. (art. 31.1).

5. El deber de realizar prestaciones personales o patrimoniales de carácter público (art. 31.3).

6. El deber de trabajar, que se reconoce junto con el derecho al trabajo (art. 35).

Dos precisiones debemos de hacer antes de entrar en el estudio pormenorizado de alguno de los principales deberes constitucionales. La primera viene determinada, como se ha puesto de manifiesto con anterioridad, en la necesidad de regulación legal de estos deberes, siendo el legislador quien establezca las sanciones que se podrán deducir de su incumplimiento, puesto que la Constitución realiza una formulación de los deberes como proposiciones jurídicas incompletas.

Hay quien, incluso, considera que la Constitución no impone por sí misma deberes constitucionales a los ciudadanos, y aunque existen diversos preceptos constitucionales que establecen como deberes la defensa de España, trabajar o contribuir económicamente al sostenimiento de los gastos públicos, se trata, en realidad, de manifestaciones esenciales de solidaridad que se colocan en un plano distinto al de las libertades públicas y los derechos fundamentales, lo que explica la necesidad de la intermediación de una ley de desarrollo 
como condición para que los deberes constitucionales sean efectivos para los ciudadanos ${ }^{14}$.

La segunda está referida a su titularidad, puesto que de su estudio se deduce la incorrección del Título de la Sección Segunda. Si bien es cierto que algunos deberes se predican sólo respecto de los españoles, el deber de defender España, y el deber de trabajar, otros se imponen a todos, con independencia de la nacionalidad o la ciudadanía del destinatario, como el deber de todos de contribuir al sostenimiento de los gastos públicos. En otros casos, como el establecimiento de un servicio militar obligatorio; el servicio civil, y el establecimiento de prestaciones personales o patrimoniales, la Constitución guarda silencio respecto a su titularidad.

Estos deberes contemplados en la Sección Segunda del Título I son deberes autónomos frente al Estado. Como ha indicado la doctrina $^{15}$, los preceptos que los enuncian no poseen una estructura similar a la de los derechos, no son derechos en negativo cuyo titular es el Estado y cuyo sujeto obligado es el ciudadano,sino que son manifestaciones específicas del poder del Estado que, por su especial trascendencia, vienen determinadas en la Constitución y están, además, acompañadas de unas garantías frente a posibles actuaciones arbitrarias de los poderes públicos, entre las que destaca el principio de reserva de ley. Los deberes expresan, de esta manera, la posición de la cualidad del ciudadano como persona dependiente del Estado, o situación de sujeción, y que no necesita una justificación especial más que la basada en el principio de la vinculatoriedad de la Constitución y el ordenamiento dentro del sistema democrático que aquélla establece.

Los deberes constitucionales configuran una especial garantía institucional en cuanto que las obligaciones impuestas por los correspondientes deberes constitucionales hacen surgir unas instituciones, de interés general, que el legislador ha de modelar, pero que, a la vez, debe proteger.

\subsection{Otros deberes constitucionales}

El Constituyente español denominó la Sección Segunda del Capí-

14 Rodríguez-Zapata, J. Teoría y práctica del Derecho Constitucional, Madrid, Técnos, 1996, pág. 309.

15 Aparicio Pérez, M. A., en Manual de Derecho Constitucional (APARICIo Pérez, M. A. y Barceló y Sarramalera, M.) (Coords.), Barcelona, Atelier, 2009, pàgs. 624 y ss. 
tulo II, del Título I, bajo la rúbrica «De los derechos y deberes de los ciudadanos», con la intención de dotar a los deberes de un tratamiento específico, sin embargo, ni todos los preceptos alusivos a deberes se encuentran en dicho Capítulo, sino diseminados a lo largo del articulado constitucional, ni unos y otros preceptos presentan la misma estructura normativa. Estos deberes, salvo el de conocer el castellano, que es un deber autónomo cuyo incumplimiento genera consecuencias jurídicas de muy diverso tipo, en realidad, contrapesos de los correspondientes derechos y su fuerza vinculante deriva, sobre todo, de la regulación que se contenga en la correspondiente ley.

Así podemos encontrar otros deberes constitucionales:

- El deber de los españoles de conocer el castellano, como lengua oficial del Estado (art. 3.1), aunque, al reconocerse que las demás lenguas españolas serán también oficiales en las respectivas Comunidades Autónomas de acuerdo con sus Estatutos (art. 3.2), se autoriza a que, por vía estatutaria, se imponga el deber de conocimiento de estas lenguas propias, que también son oficiales en sus respectivos territorios.

- El deber de los ciudadanos, y los poderes públicos, de sujeción a la Constitución y al resto del ordenamiento jurídico (art. 9.1).

- El deber de los poderes públicos de promover las condiciones para que la libertad y la igualdad sean reales y efectivas; de remover los obstáculos que impidan o dificulten su plenitud, y faciliten la participación de todos los ciudadanos en la vida política, económica, cultural y social (art. 9.2).

- El deber de proteger la dignidad del ser humano, los derechos inviolables que le son inherentes, y el libre desarrollo de la personalidad, fundamento del orden político y de la paz social (art. 10.1).

- El deber de todos a la educación básica, que es obligatoria (art. 27.4), y el deber de los poderes públicos de garantizar el derecho de todos a la educación (art. 27.5).

- Los deberes conyugales (art. 32.2).

- El deber de los padres de prestar asistencia de todo orden a los hijos durante su minoría de edad, y en los demás casos en que legalmente proceda (art. 39.3), y el deber de los poderes públicos de asegurar la protección social, económica y jurídica de la familia (art. 39.1). 
- Los deberes de todos respecto al sistema de salud pública y de protección a la salud, que serán regulados por ley (art. 43.2).

- El deber de conservar un medio ambiente adecuado (art. 45.1), y el deber de reparar el daño ocasionado al medio ambiente (art. 45.3).

- El deber de respetar el patrimonio histórico, cultural y artístico (art. 46).

- Los deberes familiares con la tercera edad (art. 50).

- El deber de todos de comparecer ante las Cámaras parlamentarias a requerimiento de éstas (art. 76).

- El deber de cumplimiento de las sentencias y demás resoluciones judiciales firmes, y el de prestar la colaboración requerida por jueces y tribunales (art. 118).

El reconocimiento específico de estos deberes, debe de ser entendido sin menoscabo de otros dos deberes, de contenido general, dirigido a los poderes públicos en materia de derechos:

- El deber de los poderes públicos de respeto a los derechos y libertades reconocidos en el Capítulo segundo del Título I, puesto que vinculan a todos los poderes públicos, $\mathrm{y}$, en especial, al poder legislativo, que sólo por ley, que deberá respetar su contenido esencial, podrá regular su ejercicio (art. 53.1).

- El deber de respeto y protección de los principios reconocidos en el Capítulo III del Título I, que informarán la legislación positiva, la práctica judicial y la actuación de los poderes públicos (art. 53.3).

Con ello, hallamos, implícitamente, imperativos dirigidos a los titulares de los poderes públicos, y a particulares, que pueden entenderse como deberes, aunque, exceptuando los deberes de los particulares, nos encontramos ante mandatos constitucionales que se dirigen a los poderes públicos y que, toda vez que sirven para acotar el poder, están dirigidos a hacer efectivo el Estado social de Derecho.

La regulación de los deberes en la Constitución, implica cierta connotación metajurídica del sistema de deberes fundamentales, si consideramos que suponen la existencia de unas situaciones de sujeción impuestas para la tutela de un interés colectivo. La Constitución hace de los destinatarios de los deberes en él recogidos a las personas, aunque del contenido de toda la Constitución, interpretada como un todo en el que cada precepto encuentra su acomodo en relación con 
los demás preceptos, podríamos determinar que en la Constitución, los deberes lo son para las personas, pero también para los poderes públicos a los que se le impone la obligación de establecer las condiciones precisas para dotar de efectividad, no solo a los derechos fundamentales proclamados constitucionalmente, sino también a los deberes. No podemos olvidar que la propia existencia de los deberes constitucionales debe de ser puesta en relación con el principio de vinculación de los poderes públicos y de los ciudadanos a la Constitución, y al resto del ordenamiento jurídico, a que se refiere el art. 9.1.

Sin pretender realizar una sistematización de los deberes, sistematización que nuestra Constitución no realiza, resulta muy interesante la realizada por De Esteban y González-Trevijano ${ }^{16}$, que toma como base las principales características del Estado Constitucional Español, y así, podemos distinguir:

- Deberes en el Estado democrático:

- Deber de estudiar.

- Deberes militares.

- Deberes en caso de grave riesgo, catástrofe o calamidad pública.

- Deberes en el Estado de Derecho:

- Deberes conyugales.

- Deberes asistenciales de los padres.

- Deber de colaborar con la Administración de Justicia.

- Deberes en el Estado social:

- Deber de trabajar.

- Deberes tributarios.

- Deberes sanitarios.

- Deber de conservación del medio ambiente.

- Deberes en la Monarquía Parlamentaria:

- Deber de comparecer ante las Comisiones de investigación.

- Deberes en el Estado de las autonomías:

- Deber de conocer el castellano.

16 de Estaban, J. y González-Travijano, P. J., Curso de Derecho Constitucional Español II, Madrid, SPFDUC, 1993, págs. 313 y ss. 


\subsection{El deber general de acatamiento y defensa de la Constitución}

Aunque cuando se habla de deberes constitucionales se suele identificar a éstos con aquellas obligaciones constitucionalizadas para los ciudadanos, los nacionales, o los sujetos particulares sobre los que ejerce su poder el Estado, no podemos olvidar que se reconoce un deber superior: el deber general de respeto a la Constitución, por un lado, y el deber particular de vinculación a los derechos, por otro, deberes que además de su mandato directo, nacen de una interpretación integrada de todos los preceptos constitucionales. Los deberes constitucionales están configurados como mandatos que vinculan, tanto a los ciudadanos como a los poderes públicos y que suponen la legitimación del plus de restricción al ejercicio de los derechos individuales que esas obligaciones acarrean.

Cuando el Preámbulo establece, como valores supremos, los principios fundamentales de la dignidad humana, la libertad, la igualdad, el imperio de la ley, la justicia, la solidaridad, la convivencia fraterna, el bienestar social, el equilibrio ecológico, el progreso y la paz, factores esenciales para la cohesión social, y el art. $9 \mathrm{CE}$ proclama que todas las personas y los órganos que ejercen potestades públicas están sujetos a la Constitución, norma suprema y fundamento del ordenamiento jurídico del Estado, está imponiendo la obediencia a la Constitución como base fundamentadota y legitimadora de una perspectiva jurídica.

La Constitución, lejos de ser un mero catálogo de principios de no inmediata vinculación y de no inmediato cumplimiento hasta que sean objeto de desarrollo, es una norma jurídica, la Norma Suprema de nuestro ordenamiento jurídico a la que están sometidos los ciudadanos y los poderes públicos a través de una vinculación inmediata, y este carácter de Norma Suprema de la Constitución a la que están sometidos todos los poderes del Estado y que resulta del ejercicio del poder constitucional del pueblo, titular de la soberanía nacional, de la que emanan todos los poderes, impide el mantenimiento de situaciones jurídicas que resulten incompatibles con los principios y mandatos constitucionales. Esta primacía constitucional exige, en primer lugar, la obligación de todos los poderes públicos respecto a la Constitución y al resto del ordenamiento jurídico, que se manifiesta en las actividades de lealtad a la Constitución en el ejercicio de sus competencias, y de obediencia, acatamiento y respeto de la misma; y en segundo lugar impone una interpretación de las normas legales acorde con la propia Constitución, puesto que la Constitución 
es una norma cualitativamente distinta a las demás, por cuanto incorpora el sistema de valores esenciales que ha de constituir el orden de convivencia política y de informar todo el ordenamiento jurídico, siendo así, no solo la norma fundamental, sino también, fundamentadora de todo el orden jurídico.

La sujeción de los poderes públicos y de los ciudadanos a la Constitución también implica, por supuesto, la sujeción a los derechos y libertades por ella reconocidas, y, por consiguiente, si los derechos y libertades son los componentes estructurales básicos, tanto del conjunto del orden jurídico objetivo, como de cada una de las ramas que lo integran, puesto que son la expresión jurídica de un sistema de valores que, por decisión del constituyente, ha de informar el conjunto de la organización jurídica y política, de la significación y finalidades de los derechos dentro del orden constitucional, se desprende que la garantía de su vigencia no puede limitarse a la posibilidad del ejercicio de pretensiones por parte de los individuos, como que ha de ser asumida, también, por el Estado.

Este deber de sujeción a los derechos fundamentales resulta, también de la combinación de los artículos 10, que fundamenta la Constitución en la dignidad humana, de la que derivan los derechos y deberes; del art. 53, que establece que los derechos fundamentales vinculan a todos los poderes públicos, los cuales deben garantizar su efectividad en los términos establecidos por la Constitución y por la ley; y del art. 9 que dispone que el Estado debe promover las condiciones jurídicas y administrativas para que la igualdad sea real y efectiva y adoptará medidas para prevenir y combatir la discriminación, la marginalidad, la vulnerabilidad y la exclusión.

Nos encontramos, de esta manera, ante dos deberes principales en el Estado Constitucional democrático: «el deber general» de acatamiento constitucional, y «el deber específico» de respeto a los derechos.

El «deber general», establece el sometimiento de los poderes públicos -y de los ciudadanos- a toda la Constitución, entendido en un sentido general, a todos y cada uno de los preceptos de la Constitución, y podríamos añadir que también al espíritu constitucional, a la esencia con que fue concebida por los constituyentes, lo que implica, en lo que se refiere a los derechos y libertades, que éstos despliegan efectos no sólo frente al Estado, sino también respecto al resto de los ciudadanos, que también se encuentran sometidos a la Constitución. El sometimiento de los poderes públicos se refiere a todos los derechos y libertades e implica, no sólo el respeto, sino también la lealtad 
respecto a ellos y la obligación de interpretar y acomodar su actuación de la forma más amplia hacia este respeto, obligación que, también determina un comportamiento positivo de los poderes públicos para dar efectividad y realidad práctica a la igualdad y a la libertad, y a los derechos y libertades que de ellos se derivan.

La segunda vinculación, puede ser observada como una «vinculación especial», es decir, los poderes públicos y los ciudadanos están sometidos a la Constitución en general, y en especial al los derechos que reconoce la Constitución, porque los derechos constituyen el pilar principal del Estado dominicano, es decir, manifiestan la finalidad propia de toda limitación del poder constitucional en un Estado de Derecho que consiste en proteger la dignidad, y con ella, la libertad y la igualdad de las personas a través de los derechos y libertades.

\section{ESTUDIO PORMENORIZADO DE ALGUNOS DEBERES CONSTITUCIONALES EN ESPAÑA}

La Constitución denomina su declaración de derechos, bajo la rúbrica «de los derechos y deberes fundamentales», pero la expresión deber no reaparece hasta el encabezamiento de la Sección Segunda del Capítulo II del Título I, bajo la rúbrica constitucional «De los derechos y deberes de los ciudadanos».

En su sentido más amplio, el concepto deber constitucional se identifica con el principio de sujeción al ordenamiento establecido en el art. 9.1, pero más allá de esta primera consideración, los deberes constitucionales reducen su alcance a la expresión de aquellas específicas obligaciones que, desde la Constitución, como norma suprema, se imponen a los poderes públicos y a los ciudadanos. Los preceptos constitucionales que enumeran deberes de los individuos, al margen de la dificultad de reducir sistemáticamente su enumeración, como consecuencia de su dispersa localización, se presentan como partes integrantes de una proposición jurídica incompleta, situación predicable, no solo de los deberes instaurados en la Sección $2^{\mathrm{a}}$, sino también de aquellos otros diseminados a lo largo del articulado constitucional.

Los deberes constitucionales suponen la existencia de unas situaciones de sujeción, impuestas para tutelar un interés colectivo, y consisten en un conjunto de prestaciones personales y patrimoniales, que vinculan la conducta de los particulares, cuyos máximos exponentes se encuentran en los artículos 30, 31 y 35 CE. En el art. 30 
aparece el deber de defender a España (servicio militar, servicio civil y la participación en casos de catástrofe o grave riesgo). El art. $31 \mathrm{CE}$ regula el deber de contribuir al sostenimiento de los gastos públicos, y el art. 35 reconoce el derecho-deber de trabajar.

\subsection{El deber de defender a España}

La Constitución configura la defensa de España como un derecho y un deber, por tanto, los ciudadanos tienen derecho a participar en la defensa de España en la forma que establezca la ley. Es un derecho de configuración legal y es, también, un deber, el deber de participar en la defensa de la nación en la forma que establezca la ley al regular las obligaciones militares de los españoles. Y en relación con el deber es donde se plantea el tema de la desobediencia civil.

El deber de defender a España ha perdido hoy gran parte de la importancia que tenía hasta el año 2002, porque en España el servicio militar era obligatorio para todos los varones y el alcance del deber era distinto. Hoy, adoptado el modelo profesional de fuerzas armadas, el deber pierde gran parte de su contenido porque desaparece la obligación de prestar el servicio militar, pero ello no quiere decir que el deber quede sin contenido, porque no se agota en la obligación de prestar el servicio militar: el deber se mantiene en su alcance genérico.

La regulación más trascendente del precepto viene referida al deber de defender España y el establecimiento de obligaciones militares, con lo que se mantiene la tradición histórico-constitucional en España, con la salvedad de que la Constitución de 1978 es la primera en clasificar la defensa de España no solo como deber, sino también como derecho.

El establecimiento de un servicio militar obligatorio, también determina las obligaciones militares, así como las causas de exención de dicho servicio, entre las que destaca «la objeción de conciencia».

Con anterioridad a la Ley 48/1984, de 26 de diciembre, reguladora del derecho a la objeción de conciencia, el TC, en la STC 15/1982, de 23 de abril, estableció que la objeción de conciencia exigía para su realización la delimitación de su contenido y la existencia de un procedimiento regulado por el legislador en los términos que rescribía el art. 30.2 CE, con las debidas garantías, y que, a falta de dicha regulación, el objetor de conciencia tenía derecho a que su incorporación a filas se aplazase hasta que se configurara un procedimiento adecuado para conferir plena efectividad al derecho del objetor. 
Posteriormente, la STC 160/1987, de 27 de octubre, estableció que la objeción de conciencia es un derecho constitucional autónomo, pero no fundamental, protegida por el recurso de amparo, no sujeto a reserva de ley orgánica.

El derecho a la objeción de conciencia, en una sociedad democrática, en un Estado social y democrático de Derecho, que se constituye sobre el consenso mayoritario expresado libremente, es el derecho a obtener la exención al cumplimiento de una norma, convirtiendo esa conducta en lícita, legítima o legal, en el entendimiento de que permitir una conducta que se separa de la norma general e igual para todos ha de considerarse como excepcional.

La STC 161/1987, de 27 de octubre, excluyó la objeción de conciencia sobrevenida, y reconoció la constitucionalidad de la competencia del Consejo nacional de Objeción de Conciencia para el reconocimiento de la objeción, así como su capacidad para comprobar la efectividad de dicha objeción y su capacidad para requerir documentación complementaria o testimonio.

También se reconoce la forma de realizar la prestación social sustitutoria al servicio militar y su distinta duración respecto al servicio militar.

\subsection{El deber de contribuir al sostenimiento de los gastos públicos}

El deber de contribuir al sostenimiento económico de la Nación, es un deber obvio y evidente, puesto que sin él, no se pueden hacer ningún tipo de políticas públicas.

El Estado social y democrático de Derecho se configura como un Estado que interviene en el ámbito social y económico de la comunidad con el objeto de conseguir las finalidades que constitucionalmente le vienen atribuidas, de manera que en este nuevo modelo de Estado, los poderes públicos asumen la función de proporcionar las prestaciones y servicios públicos necesarios para el pleno desarrollo de la personalidad ${ }^{17}$, para lo que el fenómeno tributario será el instrumento central para que se cumpla con el fin de distribuir la riqueza en aras a dar cumplimiento a la igualdad real.

17 Vid. Vidal Marín, T., Un estudio constitucional sobre el deber de contribuir y los principios que lo informan, Madrid, 1993. 
Para la Constitución española, el deber de contribución económica al sistema de gasto público, recogido en el art. 31, es básicamente el deber de pagar impuestos, y así ha sido considerado durante mucho tiempo por la doctrina, aunque en la actualidad el deber de contribuir se encuentra en la propia formulación del Estado Social, que debe obtener ingresos para la consecución de un bienestar igualitario, como la consecución de un fin de carácter constitucional.

Como ha indicado el TC (STC 50/1995), el deber de contribuir es un exponente de un interés colectivo social que le lleva a configurarse como principio básico de solidaridad de todos a la hora de soportar las cargas públicas, por lo que se pasa del deber de contribuir a nivel individual, a un marco más amplio caracterizado por el deber de solidaridad política, económica y social.

De las referencias constitucionales al deber, cabe afirmar que este deber se estructura a partir de las siguientes características:

a) La reserva de ley parlamentaria:

No hay impuestos sin representación. Históricamente, frente al absolutismo real, cuando el Rey precisa contar con bienes económicos y financieros, la exigencia que se hace al Rey es que únicamente ha de ser el Parlamento a través de la ley el que establezca el sistema tributario. La reserva de ley tiene dos centros neurálgicos, el del sistema tributario y el de la legalidad penal. En materia tributaria, la remisión al reglamento debe ser necesariamente limitada porque lo que no puede quedar en manos del gobierno es la creación de los impuestos.

b) La universalidad del deber:

De acuerdo con la redacción del artículo, "todos contribuirán», es decir, que personas físicas y jurídicas, todas las que tengan residencia fiscal en España, son sujetos pasivos de los deberes tributarios, es más, a los que están de forma transitoria en España también les afecta (la imposición indirecta).

c) La obligación individual sostenida en la capacidad económica:

Este deber es una obligación, en principio individual, sostenida en la capacidad económica personal. Con ello se quiere decir que cada uno tributa de acuerdo con su capacidad económica. Aunque el principio es la obligación individual, hay que decir, y así lo ha dicho el TC en la STC 209/88 y en la 
45/89 (ambas haciendo referencia al IRPF), que la tributación conjunta no es inconstitucional siempre que no incremente la carga tributaria que corresponde a cada uno de los sujetos pasivos. Por tanto, la acumulación familiar no puede originar incremento fiscal para cada uno de los integrantes.

d) La justicia del sistema fundamentada en la igualdad y la progresividad:

El sistema tributario debe de ser un sistema justo, que se sostiene, simultáneamente, en la igualdad y en la progresividad. La igualdad se concreta en la definición de la capacidad económica y el método para determinarla. La igualdad obliga a que tanto la definición de la capacidad económica como el método para determinarla deber ser establecidas por leyes que den a todos los sujetos pasivos del impuesto un trato igual. La progresividad, en principio, parece contradictoria por el criterio de igualdad porque el porcentaje a pagar es proporcional al nivel de renta que se tiene. El grado de progresividad se determina en función de la base imponible. El argumento de la progresividad se sustenta en el art. 9.2 CE.

e) La prohibición de la confiscación de los bienes:

Constituye una prohibición que actúa también como límite a la progresividad y es la prohibición del sistema de no poder tener alcance confiscatorio. La prohibición está afectando a la propiedad privada.

La consideración del deber de contribución económica como estado de sujeción derivado del deber de solidaridad, determina que en su determinación, la aportación equitativa resulte fundamental, pero también determina dos aspectos fundamentales: la imposición del deber jurídico de colaboración con la Administración, no solo de los contribuyentes directamente afectados, sino también de otros sujetos y entidades, para alcanzar la equidad fiscal (STC 110/1984); y la imposición a los poderes públicos de la obligación de la lucha contra el fraude fiscal (STC 76/1990).

El Auto TC 71/1993, de 1 de marzo, establece que la objeción de conciencia, en cuanto derecho constituido por una excepción a un concreto deber constitucional (el del art. $30 \mathrm{CE}$ de prestar el servicio militar sustituyéndolo, en su caso, por una prestación social sustitutoria) no puede ser extendida subjetivamente, por razón de las propias creencias más allá del ámbito objetivo del deber general que la Constitución establece. Por lo que no cabe invocar la objeción de 
conciencia como excepción al deber general previsto en el art. 31 $\mathrm{CE}$, por carecer tal pretensión de fundamento constitucional y no estar, además, prevista en el ordenamiento tributario», excluyendo así, la objeción fiscal.

\subsection{El deber de trabajar}

Se suele afirmar que el derecho al trabajo aparece por primera vez en las Constituciones de la primera posguerra europea (modelo Weimar), de donde pasó a la Constitución de la II República española, afianzándose finalmente en las Constituciones de la segunda posguerra, aunque su surgimiento es anterior.

Si hay un precepto constitucional que provoca reacciones de escepticismo generalizado, sin duda es el artículo 35, en el que el constituyente español, inasequible al desaliento que podría haber provocado en su ánimo la astronómica cifra de parados de nuestro país, ha proclamado solemnemente que «todos los españoles tienen el deber de trabajar y el derecho al trabajo», respetando así lo que constituye ya una larga tradición del constitucionalismo occidental.

Podemos afirmar, en general, que los derechos económicos y sociales» (trabajo, vivienda, salud, etc.), postulan una serie de legítimas expectativas de los ciudadanos que el Estado deberá tender a satisfacer con los medios a su alcance.

Refiriéndonos ahora concretamente al derecho al trabajo, las posturas pueden, quizás, reconducirse a tres: la primera, considera el derecho al trabajo como una mera orientación al legislador y a los poderes públicos en general, que deberán tenerlo en cuenta como criterio -más ético-político que político-jurídico- a la hora de desarrollar su concreta actividad. De acuerdo con la segunda, el derecho al trabajo implica una auténtica obligación jurídica para los poderes públicos. La tercera tesis, configuraría el derecho al trabajo como un derecho de crédito contra el Estado, constitucionalmente otorgado a todos los ciudadanos por el hecho de serlo y directamente accionable frente a los poderes públicos, con la pretensión de obtener un puesto de trabajo que, en las construcciones más exigentes, tendría que ser, además, adecuado a la capacidad profesional del accionante.

La Constitución se refiere al trabajo en varios de sus preceptos. El art. 35 de nuestra Constitución comienza diciendo: «Todos los españoles tienen el deber de trabajar y el derecho al trabajo, a la libre elección de profesión u oficio...» Por otra parte, el art. 25 párrafo 2, al 
referirse al condenado a pena de prisión, preescribe: «En todo caso, tendrá derecho a un trabajo remunerado...» Y, en fin, el art. 40 párrafo 1 , dice que «los poderes públicos... de manera especial realizarán una política orientada al pleno empleo».

Obviamente, al establecer dicho deber, el artículo 35 se refiere a algo más general y, al propio tiempo, más difuso: la obligación de desempeñar una actividad. El deber de trabajar se asienta en la solidaridad.

La mayoría de los autores continúa negando juridicidad a dicho deber de trabajar, que sería más bien de índole ético o social, que una auténtica obligación jurídica. Esta última solamente sería concebible en un sistema de economía colectivizada o, al menos, en un régimen en el cual la clase trabajadora ocupara una posición hegemónica.

Nuestra Constitución reconoce en el artículo 35 el derecho-deber de trabajar. La ubicación de este derecho dentro de la Sección $2^{a}$ del Capítulo II del Título I, determina que su protección sea menor que la otorgada a los derechos fundamentales que, como se sabe, cuentan con el recurso de amparo.

Exceptuando la consideración del trabajo como deber, que no implica su condición de deber constitucional, sino como «deber social»y, por lo tanto, jurídicamente inexigible (STC 107/1984), la configuración del trabajo como derecho es un tema de especial preocupación por dos razones fundamentales:

a) porque en nuestro tiempo el trabajo es un bien particularmente escaso ${ }^{18}, \mathrm{y}$

b) porque el derecho al trabajo es un derecho que está especialmente mediatizado por las circunstancias socioeconómicas del momento. Es un derecho pleno en su formulación y variable en su cumplimiento ${ }^{19}$.

En estas circunstancias, y como consecuencia de la importante tasa de desempleo, y de empleo inestable, que existe en la actualidad, el derecho al trabajo, según Sargadoy Bengoechea, tiene una doble dimensión: una "primaria» referida al trabajo mismo, y otra «sustitutiva», referente a la protección por desempleo. Como ha indicado el TC (STC 22/1981), el derecho al trabajo no se agota en la libertad de

18 Alonso Olea, M., El trabajo como bien escaso y la reforma de su mercado. Madrid, Cívitas, 1995.

19 Sargadoy Bengoechea, J. A., «Derechos laborales» en Comentarios a las leyes políticas. Op. cit., pág. 470. 
trabajar, sino que supone también el derecho a un puesto de trabajo, y como tal, presenta un doble contenido: en su aspecto individual se refiere al igual derecho de todos a un determinado puesto de trabajo si se cumplen los requisitos necesarios de capacitación, y en el derecho a la continuidad o estabilidad en el empleo, es decir, a no ser despedidos si no existe una causa justa; en su dimensión colectiva implica un mandato a los poderes públicos para que lleven a cabo una política de pleno empleo, pues en otro caso, el ejercicio del derecho al trabajo por una parte de la población lleva consigo la negación de ese mismo derecho para otra parte de la misma.

Las afirmaciones recogidas en el Preámbulo de la CE y en el artículo 9.2, imponen al legislador la obligación de tutelar el derecho al trabajo, y, por extensión, los derechos de los trabajadores (STC 4/1988), y suponen un mandato a los poderes públicos para que lleven a cabo una adecuada política de empleo que tienda a dar seguridad, continuidad y buenas condiciones en el mismo.

La Constitución, los Tratados Internacionales y las leyes, establecen una serie de derechos laborales básicos, que permiten definir el nuevo modelo laboral como "derecho social del trabajo ${ }^{20}$, acorde con el sistema democrático y con la concepción del Estado Social de Derecho.

\subsection{La objeción de conciencia en los deberes públicos}

Existe la duda en torno al reconocimiento de un derecho a ser dispensado del cumplimiento de los deberes constitucionales, en atención a la conciencia moral e individual de las personas, es decir, en atención a los graves escrúpulos morales que provoca a las personas, o a algunas, el ejercicio de algunas conductas. El problema que nos estamos planteando es si las personas tienen el derecho a actuar, y a conducirse, exclusivamente, de acuerdo con los dictados de la propia conciencia.

La Constitución únicamente reconoce de forma expresa la objeción al servicio militar. El art. 30.2 CE dice que la ley regulará las obligaciones militares y, con las debidas garantías, la objeción de conciencia. Esta previsión constitucional ha sido desarrollada por la Ley 22/1998 de objeción de conciencia. A partir del 31 de diciembre

${ }^{20}$ Para un mejor conocimiento del contenido y evolución de este concepto, vid., Borrajo Dacruz, E., Introducción al derecho del trabajo, 8ª Ed. Madrid, Técnos, 1995. 
de 2002 quedó suspendida la prestación del servicio militar. La Constitución en el art. 30.2 introduce una excepción al deber de cumplimiento del servicio militar obligatorio basado en convicciones religiosas, morales, éticas o humanitarias pretendiendo con ello proteger la conciencia moral de las personas frente al uso de las armas. La regulación que hace la Ley 22/1998 permite destacar que: en primer lugar que se reconoce el derecho y se adoptan cautelas por evitar el fraude. Estas cautelas se concretan en exigir que el afectado invoque las razones de la objeción, ha de hacer una declaración de sus creencias. La segunda cautela es que se excluye la objeción sobrevenida, es decir, que cuando uno sea incorporado al ejercicio a partir de ese momento no puede objetar.

La objeción no implica incumplimiento de deber, lo que se hace es variar el deber, el objetor es dispensado del servicio militar, pero debe hacer una prestación social sustitutoria, es decir, actividades de utilidad pública que no requieran el empleo de armas ni tengan relación con la institución militar.

La pregunta es si cabe otro tipo de objeción al margen de la del servicio militar. Las objeciones más frecuentes son objetar al deber tributario con argumentos de que los tributos se dedican a fines militares o energía nuclear. También aparecen objeciones relacionadas con la participación del jurado y también objeciones relacionadas con las mesas electorales. Es decir, lo que nos preguntamos es si las personas tienen un derecho a conducirse de conformidad con los dictados de su conciencia. ¿Puede funcionar una democracia sobre el presupuesto de que cada uno de nosotros puede actuar de acuerdo con los dictados de su propia conciencia?. La respuesta constitucional ha de partir del art. 9.1 CE que establece un deber genérico que afecta a todos los ciudadanos de obediencia al derecho, a la Constitución y al ordenamiento jurídico. Evidentemente obliga al derecho elaborado siguiendo los procedimientos establecidos en la Constitución, el derecho que obliga es el válidamente producido. Pero frente al derecho que no es válido el ciudadano tiene un sistema de controles y recursos jurídicos. Este principio de obediencia general tiene una única excepción, que es la reconocida en el art. 30.2 CE, la objeción de conciencia al servicio militar.

Por tanto, el ciudadano no puede atribuirse derecho a objetar más allá del art. 30.2, el ciudadano puede seguir los dictados de su conciencia, pero esta actuación carece de cobertura legal, esa actuación implica que el ciudadano debe aceptar la sanción que le impone 
el derecho, y aquí está la diferencia entre la objeción y la desobediencia civil.

Toda objeción, o excepción al cumplimiento a la ley tiene que tener cobertura legal. Es el legislador, por medio de ley, quien puede otorgar, cuando lo estime oportuno, la exención a cualquier tipo de deber. La Constitución no impide que pueda ampliarse el campo de la objeción de conciencia y su aplicación a los deberes constitucionales. La posición del TC es una posición algo más abierta que la que indicamos aquí. Básicamente, el TC ha entrado en el tema en las STC 73/85 y en la 154/2002, en materia de trasfusiones de sangre a un menor testigo de Jehová, en el primer caso, para afirmar que la conducta de los padres queda amparada en el art. 16 de libertad ideológica, y en el segundo supuesto, para reconocer la objeción de conciencia de los médicos a practicar abortos. También se ha admitido la objeción de conciencia a farmacéuticos, para la expedición en sus establecimientos de determinados medios anticonceptivos. Sin embargo, se ha negado la objeción de conciencia a los padres que la han alegado para que sus hijos estudiasen la Asignatura Educación para la Ciudadanía.

\section{BIBLIOGRAFÍA}

Arango Rivadeneira, R., Derechos, Constitucionalismo y Democracia,U. externado de Colombia. Serie de teoría Jurídica y filosofía del Derecho N ${ }^{\circ} 33$ Bogotá 2004 pág. 131.

BALDUZzI, R. (Coord), I divori vonstituzionali: la prospectiva del giudice delle legi, Actas de Congreso, Turín, Giaplichelli, 2007.

Bobbio, N., Teoría general de la Política, Editorial Trotta, 2003 Pág. 513.

BöcKEnFörde, E., Estudios sobre Estado de Derecho y democracia, Ed. Trotta, Madrid, 2000, p. 37.

CÁmara Villar, G., La objeción de conciencia al servicio militar, Madrid, Cívitas, 1991.

Camps, V., Paradojas del individualismo. Critica, Barcelona, 1999 p. 10 y 11.

De Asis Roig, R., Deberes y Obligaciones en la Constitución, Centro de Estudios Constitucionales, Madrid, 1991.

Del Vecchio, G., Persona, Estado y Derecho, Instituto de Estudios Políticos, Madrid, 1957 Pág.150. 
Haberle, P. Libertad, igualdad, fraternidad. 1789 como historia, actualidad y futuro del Estado Constitucional, Ed. Trotta, 1998.

Hanicotte, R., Devoirs de l'homme et constitutions:contribution a un theorie general du devoir, Paris, L'Harmattan, 2007.

LANDROve Díaz, G., Objeción de conciencia, insumisión y derecho Penal, Valencia, Tirant, lo Blanch, 1992.

Madiot, Y., Considerations sur les droits et les devoirs de l'homme, Paris, Bruyant, 1998.

Melin Soucramanien, F., Les Grandes Démocraties Textes des Constitutions, Armand Colin, Paris, 2005.

Peces-Barba Martínez, G., «Los deberes fundamentales». DOXA, N.4, 1988 Págs. 329-341.

Rivero, J., Les libertés Publiques, T. I Puf, Paris, 1974. Pág.64.

RoBles, Gregorio, Los derechos fundamentales y la ética en la sociedad actual, Cuadernos Cívitas, Madrid, 1992, pág. 183.

RonDEAU, D., «La relationdes droits aux devoirs: aproche interculturelle» en Revue ASPECTS, nº 1, 2008.

Rubio Llorente, F., «Los deberes constitucionales». Revista Española de Derecho Constitucional, Num. 62, Mayo Agosto 2001, Págs. 11-56.

Sánchez Viamonte, C., Manual de Derecho Político. Editorial Bibliográfica Argentina, Buenos Aires 1959 p. 3.

SIERRA PoRTO, H., «Las reformas constitucionales». Transformaciones explícitas e implícitas del Estado Colombiano No 331(Ab.2006), pág. 70.

Schmidt, T. I., Grundpflichten, Baden-baden, Nomos, 1999.

VARELA Días, S., «La idea de deber constitucional» en REDC, $\mathrm{n}^{\circ} 4$, 1992.

VIroli, M., L'Italia dei doveri, Milan, Rizzoli, 2008. 